\title{
FORMULATION AND PRODUCTION OF GRANULE FROM ANNONA MURICATA FRUIT JUICE AS ANTIHYPERTENSIVE INSTANT DRINK
}

\author{
PRASETYORINI DJAROT, MOERFIAH BADAR \\ Biology Department, Faculty of Mathematics and Natural Sciences, Pakuan University, Jl. Pakuan PO Box 452 Bogor, Indonesia \\ Email: prasetyorini@unpak.ac.id
}

Received: 07 Dec 2016 Revised and Accepted: 09 Mar 2017

\section{ABSTRACT}

Objective: The present study aims to formulate instant granule drink from soursop (Anonna muricata Linn) fruit juice and investigate its antihypertensive effect on Sprague-Dawley rats suffer from level 1 hypertensive disease.

Methods: Soursop instant granule was formulated using the wet granulation method, comprising of soursop fruit juice as the main ingredient with the addition of natrium carboxymethyl cellulose (CMC), citric acid, saccharalose, and maltodextrin as excipient and flavoring substances. The obtained granule, then administered orally to natrium chloride ( $\mathrm{NaCl}$ )-induced hypertensive Sprague-Dawley rats and the systolic and diastolic blood pressure of rats was measured subsequently on the day $4^{\text {th }}, 8^{\text {th }}, 11^{\text {th }}$ and $14^{\text {th }}$ of treatment.

Results: The granule obtained from soursop fruit juice has very good physical characteristics, colored white, has fresh sweet and sour taste with the typical smell of soursop fruit. Other physical characteristics of the granule were it has $2.9 \%$ water content ( $<5 \%$ ), $1.91 \%$ ash content, $3.13 \mathrm{ml} / \mathrm{s}$ solubility, $29.3 \%$ angle of repose, and stable in the storage at $15{ }^{\circ} \mathrm{C}$ for two months. The oral administration of soursop granule significantly decrease the systolic and diastolic blood pressure in both male and female Sprague-Dawley NaCl-induced hypertension rats.

Conclusion: The granule produced from the juice of soursop fruit has acceptable physical features and proved effective to decrease high blood pressure, hence the soursop granule could be produced as an antihypertensive instant fruit drink in an industrial scale to substitute synthetic antihypertensive drugs.

Keywords: Anonna muricata Linn, Antihypertensive medicinal herbal, Antihypertensive instant granule, Soursop fruit herbal drink

(C) 2017 The Authors. Published by Innovare Academic Sciences Pvt Ltd. This is an open access article under the CC BY license (http://creativecommons.org/licenses/by/4.0/) DOI: http://dx.doi.org/10.22159/ijpps.2017v9i5.16506

\section{INTRODUCTION}

Hypertension has become a mayor cause of mortality throughout the world and constitutes a mayor risk factor for several cardiovascular diseases such as atherosclerosis, heart failure, renal insufficiency, coronary artery disease and stroke. The risk factor increases with the age in both sexes. According to World Health Organization, about one-third of the world's population suffers from hypertension and incidence has been increasing at a rapid rate due to human modern lifestyle [1]. Many efficacious synthetic drugs have been developed for the treatment of hypertension but these drugs have been to cause side effects such as insomnia, angioedema, cough, and fetal abnormalities [2]. In response to this circumstance, herbal medicines with hypotensive activity, therefore have become the object of interest in the recent because of their ease of availability, less adverse side effects and cost-effective [3, 4$]$

Annona muricata, a precious healthy fruit widely known as graviola or soursop is easily found in most of the tropical countries and has long been used as a natural remedy for a variety of illnesses and subject of countless medicinal uses. The decoction leaves and bark of soursop traditionally believed to treat high blood pressure and diabetes [5]. These folkloric uses have been scientifically validated since the 1940s and many studies reported that the bark and leaves of the soursop tree contain antioxidant, insecticide, antipyretic, and antibacterial as well $[6,7]$. The properties and actions of soursop mostly documented by traditional uses were its ability to lower high blood pressure [8] meanwhile recent studies by different researchers demonstrated that the bark, as well as the leaves, have anti-hypertensive, vasodilator, antispasmodic (smooth muscle relaxant) and cardio depressant (slowing of heart rate) activities in animals [9]. Beside the bark and leaves, other data revealed that soursop fresh fruit also shows anti-depressive effect and toxicity against prostate PC-3 cancer cells [10].
Despite the fact that effects of medicinal plants have scientifically been proven and widely used in the modern world, very little work has been done to process these natural ingredients into more practical and easy to drink formula. Therefore, preparation of soursop juice to obtain a pleasant instant granule beverage, which also has an antihypertensive effect was considered as the main topic of this study.

Granules are agglomerates of powdered materials prepared into larger, free-flowing particles or a small compact particle of a substance. The shape of granules is generally irregular with the size typically fall within the range of $850 \mu \mathrm{m}$ (no. 20 sieve) to $4.75 \mathrm{~mm}$ (no. 4 sieves) size. Granules have a smaller surface area than a comparable volume of powders which makes this form more stable physically and chemically than the corresponding powders and are less likely to cake or harden upon standing than are powders [11]. Granulation may be defined as size enlargement process which corverts fine or coarse powder into physically larger and stronger particles. Granulation also produces particle-size uniformity, thus content uniformity.

Herbs in form of concentrated granules has gain its popularity as hot and cold instant drinks to take medicines in many markets. Individual sachets contain a single dose of granules that dissolves in water, making it easy to dose and stored for subsequent use and other advantages. Compare to other forms such as syrup or powder, the medicinal herbal in form of granule offer many advantages such as having good flow property, better compression characteristics and uniformity, easy to dose and swallow, remain stable in hot water, dissolve quickly and without leaving residues, even in cold water [12]. The granules also easily combined with colourants, flavorants, and other pharmaceutical ingredients, so the resulting solution or suspension has all the desired medicinal and pharmaceutical features of a liquid pharmaceutical. 


\section{MATERIALS AND METHODS}

\section{Chemicals and apparatus}

Tools used in the study were digital scales (AND G-120®), noninvasive blood pressure monitor (CODA, Kent Scientific Corp.), evaporator (Buchi Healthy Bath B-490, Syncore $\AA$ ), moisture balance (AND MX 50®), freeze dryer (GVD-12, Girovac Ltd), granule flow tester (EFT-10, Electrolabindia), powder tap densitometer (USP Bulk Density Tester ${ }^{\circledR}$ 315-2E), sieved (Forward FilterandFitting Co. Ltd), oven (Ney $\AA^{3}$, and glass tools. All chemicals were of analytical grade, a product of Merck and Co., Inc. and Sigma-Aldrich Inc.

\section{Preparation of plant material}

$100 \mathrm{~kg}$ of mature soursop fruits was bought from the local market in Bogor, Indonesia. The soursop fruits were then washed carefully under flowing tap water, peeled, cut into halves, and deseeded. Fruit flesh obtained were put in heat resistant containers and steamed for 4 min over boiling water. The steamed fruit flesh then keep in the refrigerator for subsequent uses.

\section{Preparation of instant granule}

The fruit flesh was placed on a plain cotton cloth and squeezed using wringer to obtain pure fruit juice. The fruit juice was dried in freeze dryer machine with the addition of $20 \%$ of maltodextrin as a filler to obtain instant fruit powder (active ingredient). The formula of instant granule was produced based on author's experimental works. The active ingredient was mixed with CMC, citric acid, sakaralose, and maltodextrin as excipient and flavouring substances as listed in the table (1). The mixture then granulated by the wet granulation method.

Table 1: Instant granule formula

\begin{tabular}{lll}
\hline Ingredients & Percentage (\%) & Weight (g) \\
\hline Soursop juice powder & 63 & 12.6 \\
CMC & 1 & 0.2 \\
Citric acid & 2 & 0.4 \\
Saccharalose & 0.1 & 0.02 \\
Maltodextrin & 33.9 & 6.78 \\
Total Weight & $100 \%$ & $20 \mathrm{~g}$ \\
Active ingredients per sachet & $12.6 \mathrm{~g}$ (equivalent to 100 g of soursop fresh weight) & \\
\hline
\end{tabular}

Soursop juice powder, CMC, citric acid, sucralose and maltodextrin were weighed according to the formula, mixed, and sieved through a 30-mesh sieve. The mixture was stirred until homogenous before sprayed with $70 \%$ ethanol sufficiently to form granule mass and dried in an oven at $40{ }^{\circ} \mathrm{C}-50{ }^{\circ} \mathrm{C}$ for $30 \mathrm{~min}$. The coarse granule obtained from this process was sieved through a 12 -mesh sieve, sprayed with $70 \%$ ethanol and dried in an oven at $40^{\circ} \mathrm{C}-50^{\circ} \mathrm{C}$ for $3 \mathrm{~h}$ and received through a 12 -mesh sieve. The obtained granule was evaluated for physical characteristics such as color, water content, ash content, solubility, the angle of repose, and stability in storage. Finally, product was packaged in a small sachet containing $20 \mathrm{gr}$ of soursop instant drink. Based on the formula above, the content of the active ingredient in each sachet drink is 12.6 gr which was equivalent to $100 \mathrm{~g}$ of soursop fresh fruit weight.

\section{Experimental design and animals acclimatisation}

The experiment in this study was conducted using randomized controlled design. Adult male and female Sprague-Dawley rats weighing between 200-250 g were prepared separately as test animals. The rats were randomly divided into 10 experimental groups (five female groups and 5 male groups, each group consisting of 10 rats). Prior to the experiment, the rats acclimatised for a period of $2 \mathrm{w}$ under a controlled environmental condition in accordance with the standard of the care and use of laboratory animals. The systolic and diastolic pressure of rats during acclimatisation period were measured using non-invasive rat tail blood pressure instrument to ensure the rats had normal blood pressure ranging from $120 / 80$ to $130 / 90 \mathrm{~mm} \mathrm{Hg}$.

\section{High blood induction and animals treatment}

In order to increase the blood pressure, rats of all experimental groups were orally administered with $2 \mathrm{ml}$ of $4.5 \% \mathrm{NaCl}$ daily for ten consecutive days. The increase in rats' blood pressure was then observed and measured. After high blood pressure induction, each group of experimental rats was treated daily with different doses of soursop granule as follows (see table 2):

Group 1 administered with $90 \mathrm{mg} / 200 \mathrm{~g}$ b. wt. soursop instant granule

Group 2 administered with $180 \mathrm{mg} / 200 \mathrm{~g}$ b. wt. soursop instant granule

Group 5 administered with $270 \mathrm{mg} / 200 \mathrm{~g}$ b. wt. soursop instant granule

Group 4 (positive control) administered with $0.45 \mathrm{mg} / 200 \mathrm{~g}$ b. wt. captopril (common antihypertensive drug)

Group 5 (normal control) administered with $2 \mathrm{ml}$ aquades/200 g b. wt.

The blood pressure of rats was measured subsequently on the day $4^{\text {th }}, 8^{\text {th }}, 11^{\text {th }}$ and $14^{\text {th }}$.

Table 2: Grouping of experimental rats based on dose of soursop granule

\begin{tabular}{ll}
\hline Groups of rat & Dose of soursop granule \\
\hline Group 1 & $90 \mathrm{mg} / 200 \mathrm{~g} \mathrm{~b} . \mathrm{wt}$. \\
Group 2 & $180 \mathrm{mg} / 200 \mathrm{~g} \mathrm{~b} . \mathrm{wt}$. \\
Group 3 & $270 \mathrm{mg} / / 200 \mathrm{~g} \mathrm{~b} . \mathrm{wt}$. \\
Group 4 & captopril $0.45 \mathrm{mg} / 200 \mathrm{~g} \mathrm{~b} . \mathrm{wt}$. \\
Group 5 & $2 \mathrm{ml}$ aquades $/ 200 \mathrm{~g} \mathrm{b.} \mathrm{wt.}$ \\
\hline
\end{tabular}

\section{Statistical analysis}

All the values of systolic and diastolic pressure were expressed as mean \pm SD (Standard Deviation). Statistical differences between the means of various groups were evaluated by Duncan's multiple range test (MRT) where means followed by the same letter in the same column are not significantly different at $\mathrm{P} \leq 0.05$.

\section{RESULTS AND DISCUSSION}

Formulation and production of soursop juice fruit instant granule

The soursop juice powder obtained from $10 \mathrm{~kg}$ of soursop fruit with the addition of $20 \%$ maltodextrin was $1.575 \mathrm{~kg}$ or equivalent 
to $1.26 \mathrm{~kg}$ pure soursop juice powder without addition of maltodextrin. This data shows that fresh soursop fruit effectively could produce $12.6 \%$ dry active ingredients. The instant drink obtained from processing soursop juice powder as the main ingredient has good physical characteristics as shown in fig. 1 appeared as bright white granule with typically fresh sour sweet taste and smell, $2.9 \%$ water content $(<5 \%), 1.91 \%$ ash content, 3.13 $\mathrm{ml} / \mathrm{s}$ solubility, $29.3 \%$ angle of repose, and stable in the storage at 15 ${ }^{\circ} \mathrm{C}$ for two months.

The physical characteristics of soursop granule produced by wet granulation method meet the industrial standard and may be considered for large-scale production of high quality antihypertensive instant fruit drink.

\section{$\mathrm{NaCl}$ induction}

Average of systolic and diastolic on male rats before and after 5.5\% $\mathrm{NaCl}$ induction is presented in the table (3).

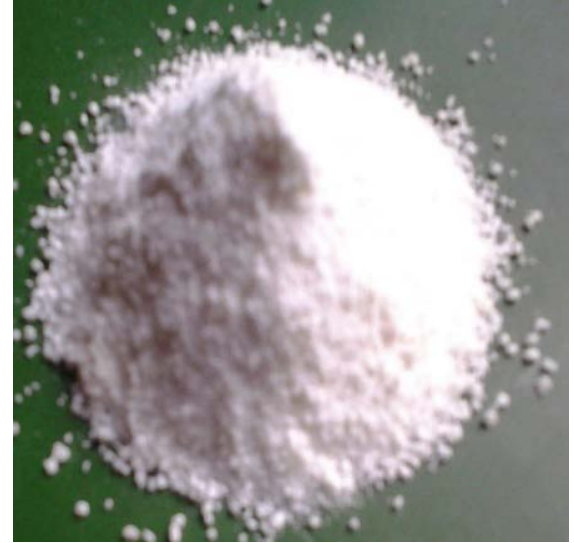

Fig. 1: Instant granule produced from juice of soursop fruit

Tabel 3. Average of sistolic and diastolic pressure of male rats after $\mathrm{NaCl}$ induction

\begin{tabular}{llll}
\hline Groups & Before induction & & After induction \\
\cline { 2 - 4 } & Systolic (mmHg) & Diastolic (mmHg) & Systolic (mmHg) \\
\hline Group 1 & $106.8 \pm 5.4$ & $86.3 \pm 8.3$ & $151.8 \pm 7.2$ \\
Group 2 & $113.5 \pm 7.6$ & $85.5 \pm 5.8$ & $149.8 \pm 7.5$ \\
Group 3 & $118.3 \pm 5.8$ & $88.0 \pm 2.7$ & $152.0 \pm 6.85$ \\
Group 4 & $124.3 \pm 2.4$ & $85.3 \pm 4.8$ & $146.5 \pm 3.4$ \\
Group 5 & $114.0 \pm 4.75$ & $88.5 \pm 8.3$ & $151.5 \pm 3.8$ \\
\hline
\end{tabular}

Data are expressed as mean $\pm \mathrm{SD}$ of ten rats in each group.

Both of systolic and diastolic pressure of all groups appear to increase after induction with $5.5 \% \mathrm{NaCl}$ for ten consecutive days. Average of systolic and diastolic pressure before $\mathrm{NaCl}$ induction were 115,4 $\pm 7,4$ $\mathrm{mmHg}$ and $86,7 \pm 4 \mathrm{mmHg}$ respectively meanwhile systolic and diastolic pressure after $\mathrm{NaCl}$ induction increased to $150,3 \pm 3,2 \mathrm{mmHg}$ and $105 \pm 5,8 \mathrm{mmHg}$ respectively. This condition indicated that all experimental rats suffer from level 1 hypertensive disease.

\section{Hypotensive effect of soursop instant granule on male rats}

The decrease of systolic and diastolic blood pressure in experimental male rats during treatment was presented in table (4) and table (5).
Table (4) and table (5) revealed significant differences between treatment groups and untreated control group in which the decrease of systolic and diastolic pressure occur in all treatment groups. Normal systolic and diastolic tension occurs on day 4 in group 4 and on day 11 in group 1,2 , and 3 .

\section{Hypotensive effect of soursop granule on female rats}

The increase of systolic and diastolic blood pressure in experimental female rats after $\mathrm{NaCl}$ induction was presented in table (6) and a decrease of systolic and diastolic pressure during treatment were presented in table (6) and table (7).

Tabel 4: Average of systolic pressure of male rats during treatment period

\begin{tabular}{|c|c|c|c|c|c|}
\hline \multirow[t]{2}{*}{ Groups } & \multicolumn{5}{|c|}{ Systolic pressure (mmHg) } \\
\hline & Day 1 & Day 4 & Day 8 & Day 11 & Day 14 \\
\hline Group 1 & $151.8 \pm 1.9$ & $147.5^{\mathrm{d}} \pm 3.0$ & $141.0^{\mathrm{bc}} \pm 4.7$ & $112.3^{\mathrm{c}} \pm 4.4$ & $109.5^{\mathrm{c}} \pm 4.7$ \\
\hline Group 2 & $149.8 \pm 1.3$ & $144.3^{c} \pm 1.6$ & $140.0^{\mathrm{b}} \pm 1.7$ & $110.0^{\mathrm{bc}} \pm 5.4$ & $107.3 b^{c} \pm 2.9$ \\
\hline Group 3 & $152.0 \pm 2.7$ & $141.8^{\mathrm{b}} \pm 1.1$ & $138.8^{\mathrm{b}} \pm 1.1$ & $106.5^{\mathrm{ab}} \pm 3.6$ & $104.0^{\mathrm{a} b} \pm 2.2$ \\
\hline Group 4 & $146.5 \pm 3.6$ & $131.3^{\mathrm{a} \pm 0.4}$ & $113.8^{\mathrm{b}} \pm 4.2$ & $102.5^{\mathrm{a}} \pm 1.7$ & $101.8^{\mathrm{a} \pm 1.5}$ \\
\hline Group 5 & $151.5 \pm 1.5$ & $148.5^{\mathrm{d} \pm 1.1}$ & $147.5^{\mathrm{c}} \pm 2.2$ & $147.8^{\mathrm{d}} \pm 2.9$ & $143.3^{\mathrm{d}} \pm 2.4$ \\
\hline
\end{tabular}

Data are expressed as mean $\pm \mathrm{SD}$ of ten rats in each group, where the means followed by same letter in the same column are not significantly different at $\mathrm{P} \leq 0.05$ according to Duncan's multiple range test.

Tabel 5: Average of diastolic pressure of male rats during treatment period

\begin{tabular}{|c|c|c|c|c|c|}
\hline \multirow[t]{2}{*}{ Groups } & \multicolumn{5}{|c|}{ Diastolic pressure (mmHg) } \\
\hline & Day 1 & Day 4 & Day 8 & Day 11 & Day 14 \\
\hline Group 1 & $101.0 \pm 0.7$ & $92.3^{\mathrm{a}} \pm 6.4$ & $88.5^{a} \pm 5.7$ & $81.4^{\mathrm{a} \pm 1.3}$ & $80.8^{a} \pm 0.83$ \\
\hline Group 2 & $106.3 \pm 2.4$ & $103.8^{\mathrm{a} \pm 4.2}$ & $89.5^{c} \pm 2.2$ & $86.3^{c} \pm 1.9$ & $83.5^{\mathrm{b}} \pm 3.34$ \\
\hline Group 3 & $112.0 \pm 5.5$ & $104.3^{\mathrm{b}} \pm 1.9$ & $88.3^{c} \pm 2.2$ & $85.8^{\mathrm{b}} \pm 2.8$ & $81.3^{\mathrm{b}} \pm 1.6$ \\
\hline Group 4 & $98.5 \pm 2.2$ & $96.5^{\mathrm{a}} \pm 2.3$ & $87.3^{\mathrm{a} a} \pm 1.9$ & $85.0^{\mathrm{b}} \pm 3.9$ & $80.8^{\mathrm{ab}} \pm 2.5$ \\
\hline Group 5 & $107.3 \pm 2.8$ & $104.0^{\mathrm{b}} \pm 5.2$ & $100.0^{b c \pm 3}$ & $98.1^{\mathrm{ab}} \pm 5.8$ & $94.3^{\mathrm{c}} \pm 1.1$ \\
\hline
\end{tabular}

Data are expressed as mean $\pm S D$ of ten rats in each group, where the means followed by the same letter in the same column are not significantly different at $\mathrm{P} \leq 0.05$ according to Duncan's multiple range test. 
Table 6: Average of systolic and diastolic pressure of female rats after $\mathrm{NaCl}$ induction

\begin{tabular}{llll}
\hline Groups & Before NaCl induction & After NaCl induction \\
\cline { 2 - 4 } & Systolic (mmHg) & Diastolic (mmHg) & Systolic (mmHg) \\
\hline Group 1 & $109.25 \pm 7.3$ & $87.50 \pm 5.4$ & $148.5 \pm 7.5$ \\
Group 2 & $101.75 \pm 4.3$ & $82.50 \pm 3.8$ & $145.5 \pm 8.66$ \\
Group 3 & $113.0 \pm 2.24$ & $91.75 \pm 7.4$ & $144.75 \pm 6$ \\
Group 4 & $119.25 \pm 6.3$ & $91.50 \pm 4.6$ & $152.75 \pm 3.8$ \\
& $106.75 \pm 6.3$ & $88.64 \pm 3.4$ & $144.35 \pm 5.3$ \\
\hline
\end{tabular}

Data are expressed as mean \pm SD of ten rats in each group.

Table 7: Average of systolic pressure of female rats during treatment period

\begin{tabular}{|c|c|c|c|c|c|}
\hline \multirow[t]{2}{*}{ Groups } & \multicolumn{5}{|c|}{ Systolic pressure (mmHg) } \\
\hline & Day 1 & Day 4 & Day 8 & Day 11 & Day 14 \\
\hline Group 1 & $148.5 \pm 7.8$ & $140.3^{\mathrm{c}} \pm 5.3$ & $129.5^{\mathrm{b}} \pm 6.1$ & $114.0^{\mathrm{b}} \pm 8.4$ & $110.8^{\mathrm{b}} \pm 5.6$ \\
\hline Group 2 & $145.5 \pm 2.2$ & $139.4^{\mathrm{bc}} \pm 4.2$ & $130.6^{b} \pm 9.6$ & $112.5^{b} \pm 2.2$ & $107.8^{\mathrm{b}} \pm 4.9$ \\
\hline Group 3 & $144.8 \pm 8.7$ & $134.5^{\mathrm{b}} \pm 4.7$ & $115.0^{\mathrm{a} \pm 9.9}$ & $105.5^{\mathrm{a}} \pm 5.0$ & $104.8^{\mathrm{ab} \pm 5.6}$ \\
\hline Group 4 & $152.8 \pm 8.8$ & $127.8^{\mathrm{a}} \pm 4.2$ & $114.0^{\mathrm{a}} \pm 4.2$ & $103.8^{\mathrm{a}} \pm 2.7$ & $101.2^{\mathrm{a} \pm 1.5}$ \\
\hline Group 5 & $144.0 \pm 2.7$ & $141.3^{c} \pm 1.3$ & $139.2^{\mathrm{b}} \pm 0.84$ & $129.4^{c} \pm 4.1$ & $124.2^{c} \pm 5.31$ \\
\hline
\end{tabular}

Data are expressed as mean $\pm \mathrm{SD}$ of ten rats in each group, where the means followed by same letter in the same column are not significantly different at $\mathrm{P} \leq 0.05$ according to Duncan multiple range test.

Table 8: Average of diastolic pressure of female rats treatment period

\begin{tabular}{|c|c|c|c|c|c|}
\hline \multirow[t]{2}{*}{ Groups } & \multicolumn{5}{|c|}{ Diastolic pressure (mmHg) } \\
\hline & Day 1 & Day 4 & Day 8 & Day 11 & Day 14 \\
\hline Group 1 & $112.8 \pm 4.6$ & $103.5^{\mathrm{bc}} \pm 4.1$ & $93.5^{\mathrm{ab}} \pm 7.0$ & $91.5^{\mathrm{a}} \pm 6.0$ & $90.3^{\mathrm{b}} \pm 5.9$ \\
\hline Group 2 & $113.5 \pm 2.8$ & $105.3^{c} \pm 4.9$ & $96.5^{\mathrm{b}} \pm 4.4$ & $91.3^{\mathrm{a}} \pm 3.6$ & $89.3^{\mathrm{ab}} \pm 4.9$ \\
\hline Group 3 & $104.3 \pm 3.9$ & $95.8^{\mathrm{a}} \pm 4.9$ & $93.8 \mathrm{a}^{\mathrm{ab}} \pm 4.0$ & $88.5^{\mathrm{a}} \pm 3.88$ & $88.5^{\mathrm{ab}} \pm 3.9$ \\
\hline Group 4 & $106.8 \pm 3.6$ & $100.3^{\mathrm{b}} \pm 1.1$ & $90.3^{\mathrm{a}} \pm 0.43$ & $88.0^{\mathrm{a}} \pm 0.71$ & $85.3^{\mathrm{a}} \pm 1.1$ \\
\hline Group 5 & $104.5 \pm 1.8$ & $100.5^{b} \pm 0.7$ & $96.8^{\mathrm{b}} \pm 1.26$ & $90.8^{\mathrm{b}} \pm 0.9$ & $92.0^{\mathrm{b}} \pm 2.45$ \\
\hline
\end{tabular}

Data are expressed as mean \pm SD of ten rats in each group, where the means followed by same letter in the same column are not significantly different at $\mathrm{P} \leq 0.05$ according to Duncan multiple range test.

Similar to the results of male rat groups, administration of the soursop granule show to decrease systolic and diastolic blood pressure of female rats. Both systolic and diastolic pressure reach its normal rate on day 4 in group 4, and on day 11 in group 1, 2, and 3. The concentration of granule affected the treatment period, the higher the concentration of granule, the shorter the treatment time. Overall, the data revealed an interesting fact that the effectiveness of soursop instant granule in decreasing systolic and diastolic pressure compares to the effectiveness of captopril were not significantly different. The difference only occurs in the treatment period in which captopril could decrease blood pressure in shorter treatment period than the granule.

The ability of soursop fruit to decrease high blood pressure possibly related to the high potassium content which found to range from $1.29 \%$ to $1.35 \%$ [13]. Potassium is important in maintaining fluid and electrolyte balance in the bodies of humans and animals where a high potassium intake will increase its concentration in the intracellular fluid. The high concentration of potassium in intracellular fluid tend to absorb the extracellular fluid which, at the end, cause to lower blood pressure $[14,15]$. Recent studes on role potassium in regulating blood pressure strengthen this assumption and has proven that the hypotensive effects of soursop fruit are not mediated through muscarinic, histaminergic, adrenergic and nitric oxide pathways, but through peripheral mechanisms involving antagonism of $\mathrm{Ca} 2+[16]$.

Other studies, however, suggest that the hypotensive properties of soursop fruit probably related to high polyphenol and antioxidant compounds found in various part of soursop fruit. Antioxidant and phenolic compounds decrease high blood pressure by increasing nitric oxide and prostacyclin formation, increasing endothelium-derived hyperpolarizing factor, mediated vasorelaxation and decreasing lowdensity lipoprotein formation and endothelial dysfunction $[17,18]$.
Hence, further research should be conduct to elucidate compounds responsible for decreasing high blood pressure in soursop fruit.

\section{CONCLUSION}

The granule produced from the juice of soursop fruit proved effective to decrease systolic and diastolic pressure in both male and female NaCl-induced hypertensive Sprague-Dawley rats. The possible mode of action of the granule might be related to high potassium and phenolic content found in the soursop fruit. The results of this study indicated that soursop granule has a potent as an antihypertensive instant drink to prevent and treat high blood pressure diseases and can be produced in industrial scale using simple and inexpensive technology.

\section{ACKNOWLEDGMENT}

This work was funded by the Ministry of Research, Technology and the Higher Education Republic of Indonesia.

\section{CONTRIBUTION OF AUTHORS}

The first and second author have participated in the work including participation in the concept, design, analysis, writing, and revision of the manuscript.

\section{CONFLICT OF INTERESTS}

Authors hereby declare that there were no conflict of interests in the accomplishment of this study.

\section{REFERENCES}

1. World Health Organization in collaboration with the World Heart Federation and the World Stroke Organization. Global atlas on cardiovascular diseases prevention and control. Geneva Switzerland: WHO Press; 2011. p. CH-1211. 
2. Yeo SK, Ooi TJ, Linn TJ, Liong MT. Antihypertensive properties of plant-based prebiotics. Int J Mol Sci 2009;10:3517-30.

3. Tabassum N, Feroz Ahmad F. Role of natural herbs in the treatment of hypertension. Phcog Rev 2011;5:30-40.

4. Najmi A, Nasiruddin M, Khan RA, Haque SF. Indigenous herbal product Nigella sativa proved effective as an antihypertensive in metabolic syndrome. Asian J Pharm Clin Res 2013;6:61-4.

5. Badrie N. Schauss AG. Soursop (Annona muricata L.): Composition, nutritional value, medical uses, and toxicology. In: Watson, R. R., and Preedy, V. R. (eds.), Bioactive foods in promoting health. Oxford; 2009. p. 621-43.

6. Kedari TS, Khan AA. Guyabano (Annona muricata): A review of its traditional

7. uses, phytochemistry and pharmacology. Am J Res Commun 2014;2:247-68.

8. Kumar S, Venkatarathanamma, Saibabu N, Ram S. Antipyretic activity of annona plants leaves on brewer's yeast induced febrile rats. Asian J Pharm Clin Res 2015;8:210-12.

9. Sushmita C, Latika S, Manoranjan PS. Phytochemical and antimicrobial screening of Annona muricata leaf extracts against clinical important gastrointestinal pathogens. J Natural Prod Plant Resource 2012;2:524-9.

10. Moghadamtousi SZ, Fadaeinasab M, Nikzad S, Mohan G, Ali MH, Habsah Abdul Kadir HA. Annona muricata (Annonaceae): a review of its traditional uses, isolated acetogenins and biological activities. Int J Mol Sci 2015;16:15625-58.

11. Patel S, Patel JK. A review on a miracle fruits of Annona muricata. J Pharmacogn Phytochem 2016;5:137-48.

12. Aulton M. Pharmaceutic: The science of dosage form design. Edinburg: Churcill Livingstone; 2000.

13. Allen LV, Ansel HC. Pharmaceutical dosage, forms and drug delivery system. 10th ed. Philadelphia: Lippincott Williams and Wilkins, a Wolter Kluwer Business; 2005.
14. Degnon RG, Adjou ES, Noudogbessi JP, Metome G, Boko F, Edwige DA, et al. Investigation on nutritional potential of soursop (Annona muricata L.) from Benin for its use as food supplement against protein-energy deficiency. Int J Biosci 2013;3:135-44.

15. Waring SW, Shahana E. 2005. How should serum uric acid concentration be interpreted in patients with hypertension. Curr Hypertens Rev 2005;1:89-95.

16. Nwokocha CR, Owu DU, Gordon A, Thaxter K, McCalla G, Ozolua RI, et al. Possible mechanisms of action of the hypotensive effect of Annona muricata (soursop) in normotensive SpragueDawley rats. Pharm Biol 2012;50:1436-41.

17. Adefegha SA, Sunday IO, Ganiyu O. Distribution of phenolic contents, antidiabetic potentials, antihypertensive properties, and antioxidative effects of soursop (Annona muricata L.) fruit parts in vitro. Biochem Res Int 2015. http://dx.doi.org/ 10.1155/2015/347673

18. Jean-Claude $\mathrm{S}$, Chataigneau T, Ndiaya M, Oka MH, Jasser BE, Chataigneau M. Vascular protection by dietary polyphenols. Eur J Pharmacol 2004;500:299-313.

19. Rajesh P. Antioxidant property of antihypertensive drugs (carvedilol, enalapril, and amlodipine) on liver function in animal (rats) models. Asian J Pharm Clin Res 2016;9:292-3.

\section{How to cite this article}

- Prasetyorini Djarot, Moerfiah Badar. Formulation and production of granule from annona muricata fruit juice as antihypertensive instant drink. Int J Pharm Pharm Sci 2017;9(5):18-22. 